\title{
MAPA DA UTILIZAÇÃO DO SOLO EM PORTUGAL
}

Dois tipos de mapas murais podem ser utilizados no ensino: os que a isso forem destinados, obedecendo a requisitos de simplicidade e de clareza, e os mapas especializados que permitam extrair-se-lhes imagens de conjunto que o professor possa fàcilmente comentar e o aluno compreender. Os Mapas de Amorim Giräo e Fernandes Martins (sete duma boa série, infelizmente incompleta, que deveria abranger as cinco partes do mundo em representação física e politica) sāo os únicos aproveitáveis, mas nada existe quanto a Portugal. Os alunos continuam a ter debaixo dos olhos mapas de Portugal com as bandeirinhas das batalhas pregadas em cima das vilas e cidades e os montes de areia, arrumados a um canto, que pretendem figurar as montanhas. $\mathrm{Na}$ falta de mapas didácticos, alguns bons mapas especializados deverão servir para tal fim, desde que, no ensino liceal ou técnico, se fala do Pais. Um mapa geológico, por exemplo, não poderá ser manejado senão nos últimos anos, pela complexidade de símbolos e pelas noções de vase que requer. Um mapa hipsométrico ou um mapa da distribuição da população podem ser explicados a uma criança. Por isso se chama a atenção dos professores para o que considero o maior êxito da cartografia de composição entre nós: a Carta Agricola e Florestal de Portugal (grandes grupos de utilização do solo) recentemente publicada pelo Serviço de Reconhecimento e de Ordenamento Agrário, dentro das normas doutros importantes trabalhos cartográficos a que noutro lugar se fez referência $\left({ }^{1}\right)$. Das três folhas a 1:250000 se pode fazer uma montagem de conjunto em dimensões que qualquer sala de aula pode comportar. Do ensino primário ao ensino superior, em todas as matérias onde seja importante conhecer o País, as suas variações e os seus contrastes regionais, este mapa devia estar sempre debaixo dos olhos de quem ensina e de quem estuda: não apenas agrónomos (a que principalmente foi destinado) nem geógrafos (clientes fiéis de toda a cartografia), mas climatólogos, naturalistas, historiadores, economistas, sociólogos, urbanistas, etc. Pela minúcia e exactidão que a escala comporta, o mapa deverá ser, no campo, assíduo companheiro de trabalho; mas os pormenores fundem-se numa imagem de conjunto tāo clara e tão vigorosa que a sua utilidade não é menor como mapa mural.

A legenda é extremamente simples: «utilização agrícola» em sequeiro e em regadio (distinção fundamental em todo o mundo mediterrâneo, dada pelo contraste entre cor de rosa pálido e azul escuro), «utilização agro-florestal» (campos arborizados, principalmente montado de sobreiro e de azinheira, mas também soutos de castanheiros no Norte interior), «utilização florestal» (principalmente pinhais mas também eucaliptais, sobreirais quando tratados em floresta, etc.), «incultos» (cumeadas e areias da beira-mar), «salinas», «rios e albufeiras» (as mais extensas criadas pelas barragens), povoações importantes. Os limites e sedes

(1) V. pp. 280. 


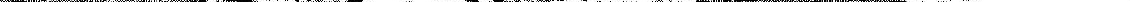

